\title{
Investigating scenario planning - a European tourism perspective
}

\author{
Albert Postma
}

Dr Albert Postma is Professor of Applied Sciences at the European Tourism Futures Institute, Stenden University, Leeuwarden, The Netherlands.
(C) Albert Postma. Published in the Journal of Tourism Futures. This article is published under the

Creative Commons Attribution (CC BY 4.0) licence. Anyone may reproduce, distribute, translate and create derivative works of this article (for both commercial \& non-commercial purposes), subject to full attribution to the original publication and authors. The full terms of this licence may be seen at: http://creativecommons.org/ licences/by/4.0/legalcode

\begin{abstract}
Purpose - The purpose of this paper is to discuss the scenario planning approach developed and used by the European Tourism Futures Institute (ETFI).

Design/methodology/approach - This paper contains the following sections: mission and aims of the research group; epistemological and methodological positioning, conceptual framework and research lines for an applied scenario planning approach.

Findings - This paper highlights the research methodology of the scenario planning group of the European Tourism Research Institute. It provides insight in the research foundations of the scenario planning approach in a tourism context and ETFl's conceptual framework for scenario planning.

Originality/value - The paper provides an insight to how Europe's first tourism futures research centre developed and uses a conceptual framework for scenario planning thus demonstrating best practice success.

Keywords Foresight, Tourism, Forecasting, Scenario planning, ETFI, Future studies

Paper type Viewpoint

\section{Introduction}

The scenario planning research group is the backbone of the European Tourism Futures Institute (ETFI). The ETFI was established in 2009 in response to an observed need in the leisure and tourism industry in the Netherlands for support with policymaking and strategic planning that takes an uncertain and increasingly complex business environment into account.

The core activity of the research group is futures studies and scenario planning, an emerging approach to strategy and planning in general and in the leisure and tourism domain in particular. Its mission is "to paint pictures of the future" for the leisure and tourism industry, primarily in Europe. More concretely the aim is to stimulate the use and application of scenario planning methods by governments, branch organisations and businesses and to make them sensitive for what might happen in the future and to learn them how to anticipate such developments by creating new business concepts, service concepts, leisure concepts, etc. The purpose of this paper is to discuss the scenario planning approach and the underlying conceptual framework adopted by the researchers of ETFI to achieve these aims.
\end{abstract}

\section{Mission and aims}

The mission of the research group is to create and share knowledge in relation to scenario planning with the leisure and tourism industry in Europe. By means of a research programme the research group wants to explore and develop state-of-the-art knowledge about futures studies and scenario planning and to develop a distinctive approach for the crafting, the use and the application of scenarios. The knowledge and expertise that is developed in the research programme is applied in an implementation programme that is composed of regional, national 
and international projects. The results of the theoretical research and of the applied projects is accessible to the academic and professional community and aims to influence policy-makers and practitioners (Figure 1).

The research group aims to capitalise its approach to scenario planning by contributing to the education of contemporary and future generations of leisure and tourism professionals [1] and by contributing to the scientific discourse of scenario planning. Thus, the research group aims to contribute to the professionalisation of the industry and the branding of the School of Leisure and Tourism in general and the ETFI in particular.

\section{Epistemological and methodological positioning}

Although the development of futures studies and scenario planning dates back to the renaissance when Thomas Moore wrote Utopia in 1516 (Moore, 1516/2009), it was fuelled by the enlightenment that separated humankind from its environment (Vining et al., 2008) and gave a boost to the idea of the feasible society. The institutionalisation of futures studies and scenario planning evolved since the Second World War, a period during which the western world was characterised by recovery and reconstruction (Ellwood, 1992; Reid, 2003) and the maturation of the idea of the welfare state in countries such as the Netherlands (Beckers and Van der Poel, 1990) and Great Britain (Henry, 2001).

Sondeijker (2009) describes three phases in the development of futures study and scenario planning, each leading to a specific type of scenarios. The first generation of scenarios that evolved after the war is strongly influenced by the work of Kahn and Diener. The approach is mainly statistical, technological and economic. Quantitative methods such as trend analysis, trend extrapolation, cross-impact analysis and growth models are the fundaments on which the approach is based. The future is interpreted as feasible and relatively surprise - free and scenarios are presented as statistical predictions in which uncertainty is interpreted as a statistical band around the projection line, i.e. single point forecasts (Sondeijker, 2009; Van Asselt et al., 2010a; Postma, 2013) In this first phase futures studies and scenario planning are mainly focused on public policy and mostly made by independent specialists (Van Asselt et al., 2010b).

During the second phase futures studies and scenario planning entered the world of business and corporate strategic planning. The oil crisis in 1973 made businesses aware about their vulnerability to unexpected external factors, which was emphasised by the influential books by Michael Porter in the 1980s. This second generation of futures studies and scenario development is strongly influenced by Wilson at General Electric (1990, 2001), by Wack at Royal Dutch Shell (Wack, 1985a,b) and by Schwartz at Stanford Research Institute and later at Royal Dutch Shell (Schwartz, 1991, 2003). Their work led to a shift from forecasting to foresighting, a more exploratory and prospective approach. With foresight it is assumed that trends from the past cannot be extrapolated linearly into the future: the globalised, digitised,

Figure 1 Scenario development between theory and practice

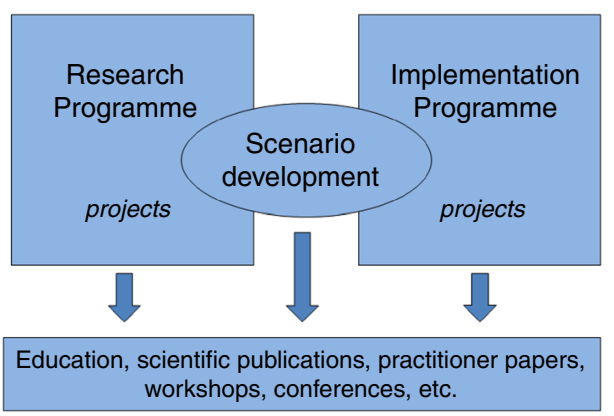

VOL. 1 NO. $12015 \mid$ JOURNAL OF TOURISM FUTURES $\mid$ PAGE 47 
hyper connected, complex and exponentially changing world leads to uncertainties and unexpected external factors (wild cards) that cause disruptions and discontinuities of trends. This might result in sudden discontinuities of trends making them unreliable as a basis for corporate strategy. Instead, key uncertainties of the business environment that drive the future of the business are used as a framework to delimit multiple alternative yet plausible futures, each illustrating a direction to which the business could evolve. Ideally, the scenarios are made in a facilitated process with participants from science and practice, and from different disciplinary and professional backgrounds. Creativity and imagination are important competencies in this participatory development process. The scenarios are intended to act as source of inspiration for the identification of innovative courses of action with which the future can be anticipated (Sondeijker, 2009; Van Asselt et al., 2010b; Postma, 2013).

Sondeijker (2009) identifies a propagation of a third generation in futures studies and scenario planning that arose after the publication of the Brundtland Report in 1987 (United Nations World Commission on Environment and Development (UNWECD), 1987) and the Earth Summit in Rio de Janeiro in 1992 (Earth Summit, 1992) and which is still in progress. This approach is fuelled by the notion of sustainable development and is based on the assumption that a more sustainable world can only be created by means of a structural and societal transition of society. Scenarios from the first two generations are not appropriate to fulfil this need as it requires a holistic, systemic, integrative, participatory, reflexive, comprehensive and anticipative as well as adaptive approach: they should pursue environmental, social and economic concerns jointly (Sondeijker, 2009; Postma et al. , 2013; Postma, 2001). In fact, this third generation of so-called transition scenarios are hardly put in practice yet: uncertainties and wild cards are often not taken into account and anticipated changes are often incremental (Sondeijker, 2009).

Sondeijker (2009) expects that futures studies will experience fundamental changes in several years. She beliefs that long-term, complex and uncertain processes in society should be controlled proactively. Within futures studies she expects a return to long-term research based on macro-thinking and explaining the big picture, i.e. grand patterns of social change. She expects that scenario development will increasingly have to pay attention to the winners and losers of the idealised futures.

The first generation of futures studies and scenario planning (forecasting) is based on a positivist epistemology and the second and the third (foresight) on a social-constructivist epistemology (Postma, 2013). Positivism is grounded in physical science. It is based on the paradigm that the social world is organised by objective and universal truths and regularities from which human behaviour can be predicted and so it is assumed that developments, patterns and trends can be projected linearly and unambiguously into the future. Social constructivism is grounded in the belief that the world is a result of a mental and subjective construct of individuals and thus composed of multiple realities (Thorpe et al., 2008).

In tourism futures studies and scenario planning are still in its infancy. Paying attention to the future started in the 1960s and 1970s in the USA and in Europe with an emphasis on forecasting of demand. For reasons of inaccuracy and decreasing urgency, the method gradually lost favour in the 1980s and 1990s (Veal, 1999). Although forecasting might continue to play a minor role in tourism, the drive for innovations in a competitive market forces the industry to explore trends and developments and to develop pro-active strategies (Buhalis and Costa, 2006). Gradually, in tourism scenario planning of the second generation started to evolve since the early 2000s. The ETFI wants to play a significant role in the development of futures studies and scenario planning in tourism, to the professionalisation of the approach and to the education of contemporary and future professionals. The emphasis will be on foresight of the second generation (alternative futures), positioned in the social constructivist paradigm, with an open eye to forecasting (first generation) and transition scenario planning (third generation).

\section{Conceptual framework}

Basically, scenario planning can be regarded as a continuous process in which the future is studied and analysed, main drivers and uncertainties are identified, scenarios are compiled and innovative measures are taken on basis of these scenarios (Figure 2). 


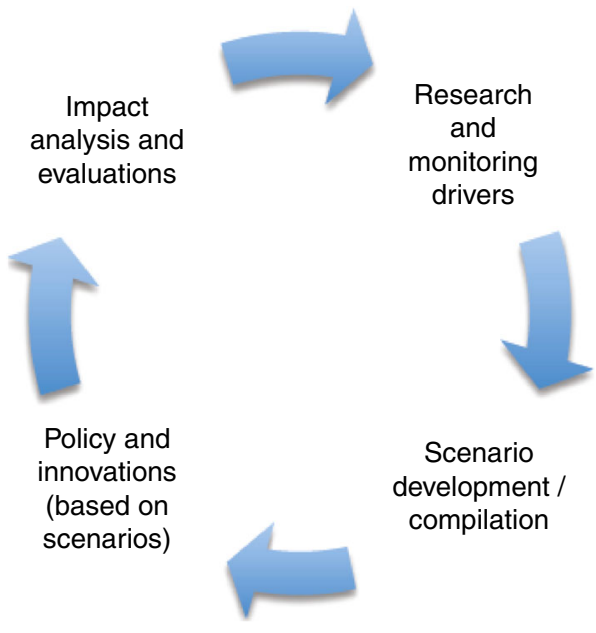

For academic purposes this scenario cycle can be critiqued for a few reasons. In the first place it is a very general model. It lacks a time perspective and the dimension of speed of change (exponential growth). The model does not explicate that neither trends nor extrapolations of trends are taken as a starting point, but uncertainties instead. Besides, it suggests a cycle of continuous improvement, which is not very realistic. Positive about such a cyclical model is that it fits well with education, that it is easy to explain and has practical value.

The Research Group Scenario Planning at the ETFI adapted the model to the one used by the Dutch Planbureau voor de Leefomgeving (Planbureau voor de Leefomgeving, 2012). This has resulted in a scenario cycle in which the concepts are positioned along the dimension of time (from present to future) and the dimension of specificity (from concrete to abstract). The model is used as conceptual framework for the research programme of the Research Group Scenario Planning.

The model shows how concrete actions in the present are affected by abstract certainties and uncertainties in the future. The certainties and uncertainties are used for the crafting of future scenarios. These scenarios inform policymaking and strategic planning, which could, in turn, be translated into concrete actions.

\section{Research lines}

The cycle in Figure 3 reflects how scenario planning is executed according to ETFI's vision. Each phase and intersection point in the cycle represents theoretical and practical problems and formal and informal research themes and research lines. In order to develop and professionalise the scenario planning process further, knowledge should be developed according to the research themes/lines as described in the interdependent research lines (1) to (7) in Figure 4.

Ideally the research lines should link theory to practice (concrete case studies of a business, leisure sector or destination), involve students (projects, internship or BBA/M thesis) and businesses, as was reflected in Figure 1.

\section{(1) Scenario planning and planning paradigms}

The first research line is largely fundamental in nature. It focuses on the evolvement of the subsequent generations of futures studies and scenario planning and the emergence of the third generation of transition scenarios and its implications and possible use for the tourism industry. Here, it is important to link it to the latest insights in organisational learning and the latest developments in planning paradigms, such as adaptive planning. The research is also related to 


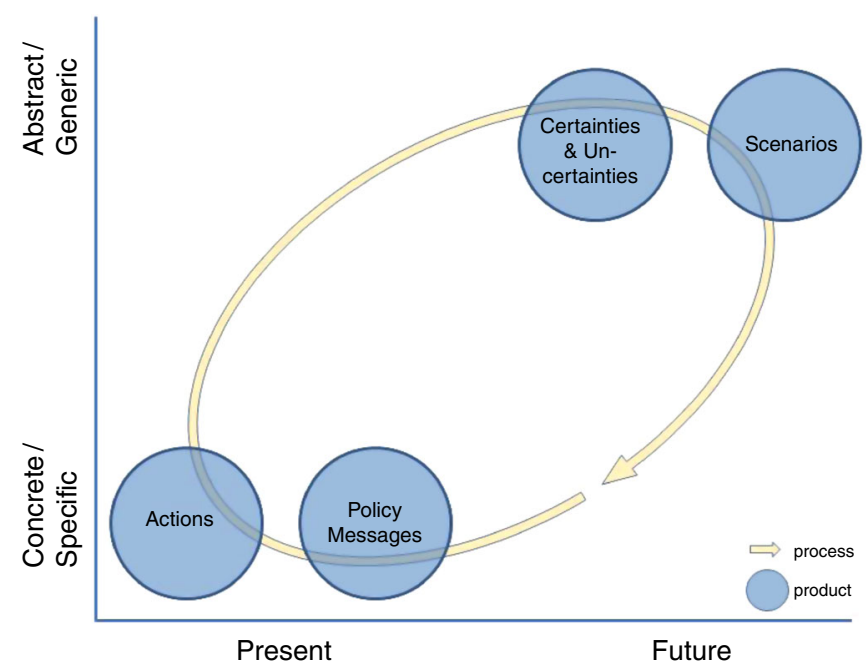

Figure 4 Research lines in relation to the conceptual framework

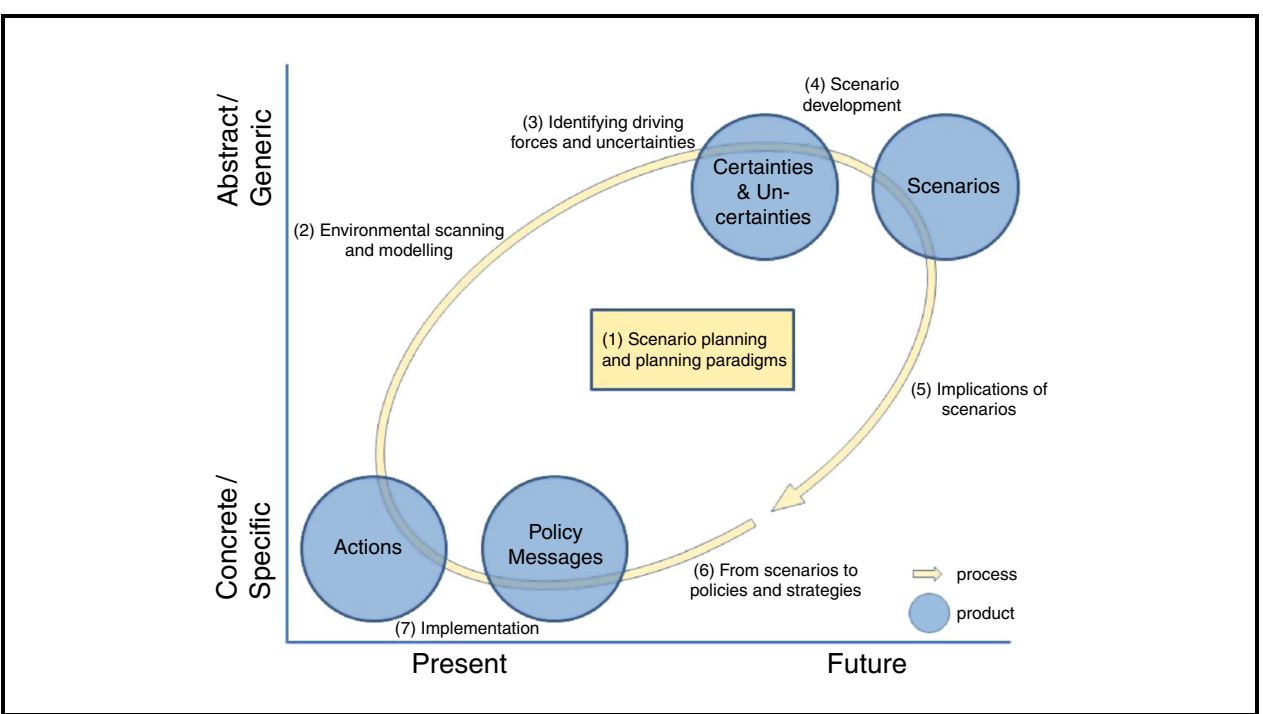

structural characteristics of different types of businesses, organisations and destinations (phase of development, culture, entrepreneur styles, etc.).

\section{(2) Environmental scanning and modelling}

Scenario planning starts with understanding the business environment. The members of the interdisciplinary research group and associated businesses monitor and discuss contemporary developments and its relevance to tourism on a regular basis and thus jointly give meaning to what is expected to drive tourism in the years to come. Information communication technology might provide a communication platform for this monitoring across disciplines, actors and networks.

\section{(3) Driving forces and uncertainties}

The third research line focuses on how the macro analysis of the environment is reduced and modelled to an insightful set of driving forces and uncertainties on which scenarios can be built. 
As, in line with the social constructivist starting points, it is believed to be a participatory process with different stakeholders, research will have to support the facilitation of this communication and learning process.

\section{(4) Crafting of scenarios}

In line with contemporary insights of scenario planning, the ETFI formulated its mission as "painting pictures of the future of leisure and tourism". This implies that the making of scenarios is a craft that requires creativity and the ability to tell appealing stories. Storytelling, imagineering, visualisation of scenarios, for instance by making use of contemporary technologies, will be the main focus of research in this research line.

\section{(5) Implications of scenarios}

In this research line the emphasis is on developing procedures and (simulation) models for ex ante evaluations of the scenarios to understand the (integrated) social, economic and environmental impacts at business level, organisational level or at destination level, and at risk assessment.

\section{(6) From scenarios to policies and strategies}

The intention of scenarios is that organisations, businesses or destinations take measures that make them more resistant against future developments that might otherwise affect their market position and competitive power negatively. However, the translation of scenarios into policies and strategies seems to be one of the weaknesses of scenario planning yet. The research focuses on how this can be improved.

\section{(7) Implementation}

The final research line focuses on how businesses, organisations and destinations can be guided with the implementation of future thinking, the use of scenarios and the effectuation of proposed measures. This is connected to, for example, change management, networks, cooperation, communities of practice, education of businesses, organisational learning, etc.

\section{Concluding thoughts}

The ETFI started its operations in 2010. During the first four years of its existence, the research team has conducted several local, regional, national and international studies. The works was acknowledged by the Dutch government and the ETFI became one of the pillars of the national Centre of Expertise in Leisure, Tourism and Hospitality (CELTH). In the years to come the institute hopes to strengthen its name in the tourism industry in Europe and beyond by giving significant contributions to theory, practice and education of scenario planning.

\section{Note}

1. In the BBA programmes of International Tourism Management and Leisure Management.

\section{References}

Beckers, T. and Van der Poel, H. (1990), Vrijetijd tussen vorming en vermaak. Een inleiding tot de studie van de vrijetijd, Stenfert Kroese, Leiden/Antwerpen.

Buhalis, D. and Costa, C. (Eds) (2006), Tourism Business Frontiers. Consumers, Products and Industry, Elsevier/Butterworth Heinemann, Oxford.

Earth Summit (1992), "Rio declaration on environment and development", UN Conference on Environment and Development, Rio de Janeiro, 3-14 June 1992, available at: www.un.org/documents/ga/conf151/ aconf15126-1annex1.htm (accessed 20 November 2011).

Ellwood, D.W. (1992), Rebuilding Europe: Western Europe, America, and Postwar Reconstruction, Addison-Wesley Longman, London.

Henry, I.P. (2001), The Politics of Leisure Policy, 2nd expanded and updated ed., Palgrave MacMillan, Basingstoke.

Moore, T. (1516/2009), Utopia, Barnes \& Nobles Classics Series. Barnes \& Noble, New York, NY. 
Planbureau voor de Leefomgeving (PBL) (2012), Natuurverkenning 2010-2040. Visies op de ontwikkeling van natuur en landschap, Planbureau voor de Leefomgeving, Den Haag.

Postma, A. (2001), "An approach for integrated development of quality tourism", paper presented at ATLAS 10th Anniversary Conference, "Tourism, innovation and regional development", Dublin, 2001, in Andrews, N., Flanagan, S. and Ruddy, J. (Eds) (2002) Tourism Destination Planning, Tourist Research Center, Dublin Institute of Technology, Dublin.

Postma, A. (2013), “Anticipating the future of European tourism”, in Postma, A., Yeoman, I. and Oskam, J. (Eds), The Future of European Tourism, European Tourism Futures Institute, Leeuwarden, pp. 290-305.

Postma, A., Spruyt, E. and Cavagnaro, E. (2013), Sustainable Tourism 2040. A Manifesto, European Tourism Futures Institute, Leeuwarden.

Reid, D. (2003), Tourism, Globalisation and Development. Responsible Tourism Planning, Pluto Press, London.

Schwartz, P. (1991), The Art of the Long View: Planning for the Future in an Uncertain World, Currency Doubleday, New York, NY.

Schwartz, P. (2003), Inevitable Surprises. Thinking Ahead in Time of Turbulence, Gotham Books, New York, NY.

Sondeijker, S. (2009), "Imagining sustainability. Methodological building blocks for transition scenarios”, PhD Dissertation, Erasmus University, Rotterdam.

Thorpe, R., Easterby-Smith, M., Lowe, A. and Jackson, P.R. (2008), Management Research, Sage, London.

United Nations World Commission on Environment and Development (UNWECD) (1987), Our Common Future, Oxford University Press, Oxford.

Van Asselt, M.B.A., Faas, A., Van der Molen, F. and Veenman, R. (Eds), (2010a), Uit zicht. Toekomstverkennen met beleid, Wetenschappelijke Raad voor het Regeringsbeleid/Amsterdam University Press, Amsterdam, The Netherlands.

Van Asselt, M.B.A., Van 't Klooster, S.A., Van Notten, P. and Smits, L.A. (2010b), Foresight in Action: Developing Policy-Oriented Scenarios, Earthscan, London.

Veal, A.J. (1999), Research Methods for Leisure and Tourism. A Practical Guide, Prentice Hall, London.

Vining, J., Merrick, M.S. and Pice, E.A. (2008), "The distinction between humans and nature: human perceptions of connectedness to nature and elements of the natural and unnatural", Human Ecology Review, Vol. 15 No. 1, pp. 1-11, available at: http://biophiliccities.org/wp-content/uploads/2012/06/ DistinctionBetweenHumansNature.pdf (accessed 18 November 2011).

Wack, P. (1985a), "Scenarios: uncharted waters ahead”, Harvard Business Review, Vol. 63 No. 5, pp. 72-89. Wack, P. (1985b), "Scenarios: shooting the rapids", Harvard Business Review, Vol. 63 No. 6, pp. 139-50.

Wilson, I. (1990), "The state of strategic planning. What went wrong? What goes right?", Technological Forecasting and Social Change, Vol. 37 No. 2, pp. 103-11.

Wilson, I. (2001), "From scenario thinking to strategic action", Technological Forecasting and Social Change, Vol. 65 No. 1, pp. 23-30.

\section{Further reading}

Wilson, I. (1994), "Strategic-planning isnt dead - it changed", Long Range Planning, Vol. 27 No. 4, pp. 12-24.

\section{Corresponding author}

Dr Albert Postma can be contacted at: albert.postma@stenden.com 